\title{
Effect of using two levels of bread yeast Saccharomyces cerevisiae on some economic traits of Arabian dam
}

\author{
${ }^{1}$ Husam Ali Majeed Al-Zubaedi , ${ }^{2}$ Meitham K, Ali AL-Galiby \\ ${ }^{1,2}$ Faculty of Agriculture and Marshlands, University of Thi-Qar, Iraq \\ ${ }^{1}$ Email: Alimjed35@gmail.com
}

\begin{abstract}
This study was conducted in the animal field of the College of Agriculture and the Marshes / University of Dhi Qar for the period from 11/6/2020 to 16/2/2021. In this experiment, (12) Arabi dairy sheep were used with their lambs ranging in age from one and a half to two years, single and close in birth. The times of their birth, and their average initial weights were $(43.90,48.50,44.60) \mathrm{kg}$ for the first, second and third treatments, and after giving the ewes a preparatory stage for two weeks, the ewes and their lambs were randomly distributed between three treatments (nutrition) equally, and each treatment was four replicates, and the ration was given to the ewes on the basis of $3 \%$ The ewes of the first treatment were fed a control ration consisting of (25\% barley, $25 \%$ wheat bran, $20 \%$ crushed corn, $20 \%$ flour, $7 \%$ soybean meal and 3\% salt) and the second treatment (basic ration $+3 \mathrm{gm}$ yeast /head /day) and the third treatment (basic diet +5 gm yeast /head/day) and straw was provided freely to all the mothers of the different treatments. The weights, weight increases and the amount of feed consumed were recorded. Presence Excellence moral $(0.05 \geq P)$ inThe lambs weighed, and there was a moral superiority $0.05 \geq \mathrm{P})$ in the second week of the experiment only for the treatment ( $3 \mathrm{gm}$ yeast / head / day) Its value was (16.47) $\mathrm{kg}$ compared toworth transactions, while There are no significant differences in the rate of total and daily weight gain of lambs in all treatments Experience On Although there was an arithmetic increase in favor of the treatment ( $5 \mathrm{gm}$ yeast /head /day).
\end{abstract}

\section{INTRODUCTION}

Livestock in Iraq suffers from low productivity and scarcityaits counter due to the lack of availabilityNoFeed and its nutritional value is low due to its low protein and energy contentThan aThis is the direction of theaLooking to use theaNatural food additive made from aTheir concern is the use of a bio-enhancer is a group of a Microscopic modesty and beneficial Painservice Widely In feeding ruminants to improve Rue environment Digestion lab dry matter andthen raise Productivity of animals living under stressful conditionsSchingoethe and others 2004, Moallem et al. 2009). It is yeast Saccharomyces cerevisiae is one of the most importantaExisting microscopic shyness in a The bio-booster has been aInclusion in the diets of ruminants ,toaIt improvesbenefit Manalapoor quality coarse feed (Shriver- Munsch and others 2011) Use of baking yeast led to Improving productive performance and disease prevention by maintaining a healthy digestive system and improving bowel functions (Chaucheyras-Durand and others 2008). aIn addition to that and boost rumen microbial ecosystem (Musa 2009and others)It reduces greenhouse gas emissions (Pedraza-Hernández and others 2018, Vallejo-Hernández and others 2019(increased digestibility)kewan ; El-Ghani, 2004 and others 2019), absorb

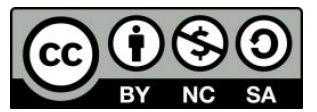

Page74

UTJagr This is an open access article under the CC-BY-NC-SA license (https://creativecommons.org/licenses/by-nc-sa/) 
nutrients and improve feed conversion efficiency ratio for feed( Antonoviand others 2006; Whitleyand others 2009), improve animal performance and prevent lactic acid buildup (Jouany Morgavi 2007). The study aimed to use yeast bread to improve the characteristics ofaLow nutritional value feed used to improve economic characteristics Such as animal weights, weight increases and consumed feed.

\section{MATERIALS AND WORKING METHODS}

This study was conducted in the animal field of the College of Agricultureand the Marshes / University of Dhi Qar for the period from 11/6/2020 to 16/2/2021. In this experiment, (12) Arabi sheep were used with their lambs ranging in age from one and a half to two years, single and close in birth. The times of their birth, and their average initial weights were $(43.90,48.50,44.60) \mathrm{kg}$ for the first, second and third treatments, and after giving the ewes a preparatory stage for two weeks, the ewes and their lambs were randomly distributed between three treatments (nutrition) equally, and each treatment was four replicates, and the ration was given to the ewes on the basis of $3 \%$ The ewes of the first treatment were fed a basic diet consisting of (25\% barley, $25 \%$ wheat bran, $20 \%$ crushed corn, $20 \%$ clay, $7 \%$ soybean meal, and $3 \%$ salt) and the second treatment (basic ration $+3 \mathrm{gm}$ yeast/head/day) and the third treatment (basic diet +5 gm yeast/head/day) and hay was provided freely to all the sheeps of the different treatments. The animals were examined by the veterinarian and all veterinary measures were taken for the herd throughout the study period, when the ewes and their lambs were dosed against external parasites with lvermectine subcutaneously, ewes were injected with $2 \mathrm{ml}$ subcutaneously and lambs $1 \mathrm{ml}$. The animals were also injected with Albendazole against internal worms. The weights of the animals were calculated by weighing every two weeks to adjust the amount of feed. The weight continued until the end of the experiment. The weight increases were calculated and the amount of feed consumed by the animals was calculated by the difference between What is provided to the animals of fodder and what is left in the feed daily.

Table (1) The chemical composition of the study suspension.

\begin{tabular}{|l|l|}
\hline The ratio $\%$ & Nutrients \\
\hline 83.09 & dry matter \\
\hline 16.5 & raw protein \\
\hline 1.72 & ether extract \\
\hline 5.85 & raw fiber \\
\hline 2.79 & ash \\
\hline 69,63 & soluble carbohydrates \\
\hline 2771 & $\begin{array}{l}\text { Energy represented } \\
\text { megamol } / \mathrm{kg}\end{array}$ \\
\hline
\end{tabular}




\section{III.DISCUSSION RESULTS}

\section{1- live body weight}

Effect of body weight forFor two coefficients (control and3 and 5 gm yeast / head / day) did not appear there spiritual qat fur $(\geq 0.05 \mathrm{p})$ at starting weight and 4, 6, 8, 10, and 12 weeksa On Although there is a clear arithmetic increment in favor of transaction lambs ( $3 \mathrm{gm}$ yeast $/ \mathrm{kg}$ of feed) and the significant differences appeared $(0.05 \geq \mathrm{p})$ only at the second week of the study with the superiority of the treatment ( $3 \mathrm{gm}$ yeast $/ \mathrm{kg}$ of feed) which had an average weight (16.47) $\mathrm{kg}$ compared to the control treatment, whose average weight was $(14.15) \mathrm{kg}$, and the treatment did not differ (5 gm yeast $/ \mathrm{kg}$ of feed) which had an average weight of $15.25 \mathrm{~kg}$ for my treatment (control and $3 \mathrm{gm}$ yeast $/ \mathrm{kg}$ of feed). The reason may be that adding yeast to animal diets improved rumen conditions and increased the number of microorganisms In it, especially the total and decomposing bacteria of cellulose, yeast is also rich in minerals and vitaminsThis study agreed with all of the Elaref and others (2020) al-Ghaliby et al. (2017)Ahmad and others (2016) and Abu Salwa (2016).

Table (2) average body weight tofor lambs ( $\mathrm{kg}$ ) for groups fed on Different levels of baking yeast Compared with the control group (Saccharomyces cerevisiae) ( \pm standard deviation)

\begin{tabular}{|l|l|l|l|l|l|l|l|}
\hline \multicolumn{2}{|l|}{ weights lambs } & \multirow{2}{*}{$\begin{array}{l}\text { Transact } \\
\text { ions }\end{array}$} \\
\hline \multicolumn{2}{|l|}{ the week } \\
\hline 12 & 10 & 8 & 6 & 4 & 2 & 0 & \\
\hline $27.49 \pm$ & $25.82 \pm$ & 23.14 & $20.24 \pm$ & $17.17 \pm$ & $14.15 \pm$ & $12.10 \pm$ & $\mathrm{T} 1$ \\
2.61 & 2.51 & \pm 2.42 & 2.58 & 2.36 & $1.12 \mathrm{~b}$ & 1.21 & \\
\hline $29.15 \pm$ & $27.22 \pm$ & 24.37 & $22.02 \pm$ & $18.22 \pm$ & $16.47 \pm 1$. & $14.00 \pm$ & $\mathrm{T} 2$ \\
4.44 & 3.48 & \pm 3.52 & 2.93 & 2.21 & $07 \mathrm{a}$ & 1.01 & \\
\hline $29.42 \pm$ & $25.90 \pm$ & 23.07 & $20.02 \pm$ & $16.92 \pm$ & $15.25 \pm$ & $13.60 \pm$ & T3 \\
5.90 & 4.27 & \pm 3.95 & 3.27 & 2.45 & $1.72 \mathrm{ab}$ & 0.87 & \\
\hline $\mathrm{N}$ & $\mathrm{N}$ & $\mathrm{N}$ & $\mathrm{N}$ & $\mathrm{N}$ & 0.05 & $\mathrm{~N}$ & morale \\
\hline
\end{tabular}

* Averages that carry lettersa different significantly differ at the level of significance $(0.05 \geq \mathrm{p})$.

$\mathrm{T} 1=$ control treatment (free of E addition).

$\mathrm{T} 2=$ second treatment $(3 \mathrm{gm}$ yeast $/ \mathrm{kg}$ of feed $)$

$\mathrm{T} 3=$ treatment for the third $(5 \mathrm{gm}$ yeast $/ \mathrm{kg}$ of feed $)$.

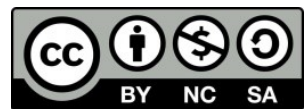

Page76

UTJagr This is an open access article under the CC-BY-NC-SA license (https://creativecommons.org/licenses/by-nc-sa/) 


\section{2-Weight increases}

Table (3) shows the rates of daily weight gain and total weight gain during the study period. There were no significant differences $(0.05 \geq \mathrm{p})$ among lambs treated (control, 3 and $5 \mathrm{~g}$ yeast $/ \mathrm{kg}$ of feed) On Although there is a clear arithmetic increment in favor of the transaction lambs ( $5 \mathrm{gm}$ yeast $/ \mathrm{head} /$ day) The rates of total and daily weight gain for the control group and the lambs group that were given ( 3 and 5 gm yeast /head/day) were $(15.39,15.15,15.82) \mathrm{kg}(183.21,180.35$, 188.33) g/day, respectively.

Yeast was added to it to adapt the rumen environment to receive the new nutrients that are used to feed ruminants, thus enabling the availability of appropriate types of microorganisms to digest the nutrients entering the rumen, as it increases cellulose-digesting bacteria and reduces lactate-producing bacteria. study ElarefOthers (2020) foundChashinidel and others (2020) Ahmad and others (2016), Al-Ghalbi (2017) and Abu Salwa (2016).

Table (3Total and daily weight increasestoFor lambs of the control animal group and the groups fed different levels of bread yeast (Saccharomyces cerevisiae) ( \pm standard deviation)

\begin{tabular}{|l|l|l|}
\hline $\begin{array}{l}\text { daily weight gain } \\
(\mathrm{g} / \text { day }) \text { for lambs }\end{array}$ & $\begin{array}{l}\text { Total weight gain }(\mathrm{kg}) \\
\text { for lambs }\end{array}$ & Transactions \\
\hline $183.21 \pm 12.1$ & $15.39 \pm 1.12$ & $\mathrm{~T} 1$ \\
\hline $180.35 \pm 13.13$ & $15.15 \pm 1.07$ & $\mathrm{~T} 2$ \\
\hline $188.33 \pm 15.03$ & $15.82 \pm 1.05$ & $\mathrm{~T} 3$ \\
\hline N.S & N.S & morale \\
\hline
\end{tabular}

The averages with different letters differ significantly at the level of significance $(0.05 \geq p)$.

$\mathrm{T} 1=$ control transaction (free of any addition).

$\mathrm{T} 2=$ second treatment $(3 \mathrm{gm}$ yeast $/ \mathrm{kg}$ of feed $)$

$\mathrm{T} 3=$ treatment for the third $(5 \mathrm{gm}$ yeast $/ \mathrm{kg}$ of feed $)$.

\section{3- Amount of feed consumed and feed conversion efficiency}

Table (4) shows There were no significant differences $(0.05 \geq \mathrm{p})$ in the amount of feed consumed for lambs of the different treatments, and the treatment was (3 gm yeast $/ \mathrm{kg}$ of feed) which was averaged (54.36) $\mathrm{kg}$ is the mathematically superior in the amount of feed consumed, followed by the treatment ( $5 \mathrm{gm}$ yeast $/ \mathrm{kg}$ of feed(which was the average feed consumed throughout the study)54.20) kg, and the control treatment (49.88) $\mathrm{kg}$ came in the last place, and that there was no significant superiority between the feed consumed due to animal feeding, it was group feeding, not individual, as for 
the efficiency of feed conversion for lambs It was a transaction ( $3 \mathrm{gm}$ yeast/head/day) was superior in feed conversion efficiency, whose value was (3.58) $\mathrm{kg}$ of feed / $\mathrm{kg}$ of live weight.a followed by treatment ( $5 \mathrm{gm}$ yeast/head/day), whose average nutritional conversion efficiency was $(3.42) \mathrm{kg}$ feed $/ \mathrm{kg}$ weight.a alivea In the last place came the control treatment, whose amount was $(3.24$

Table (4Amount of feed consumed and feed conversion efficiencytoFor lambs of the control animal group and the groups fed different levels of bread yeast (Saccharomyces cerevisiae) for the duration of the study ( \pm standard deviation)

\begin{tabular}{|l|l|l|}
\hline $\begin{array}{l}\text { Efficiency of } \\
\text { feed conversion } \\
\text { of lambs }\end{array}$ & $\begin{array}{l}\text { Feed consumed } \\
\text { (kg) for lambs }\end{array}$ & Transactions \\
\hline $3.24 \pm 1.11$ & 49.88 & $\mathrm{~T} 1$ \\
\hline $3.58 \pm 1.04$ & 54.36 & $\mathrm{~T} 2$ \\
\hline $3.42 \pm 1.12$ & 54.20 & $\mathrm{~T} 3$ \\
\hline N.S & & morale \\
\hline
\end{tabular}

The averages with different letters differ significantly at the level of significance $(0.05 \geq p)$.

$\mathrm{T} 1=$ control transaction (without any addition).

$\mathrm{T} 2=$ the second treatment $(3 \mathrm{gm}$ yeast / head / day $)$.

$\mathrm{T} 3=$ treatment for the third $(5 \mathrm{gm}$ yeast $/$ head $/$ day $)$.

\section{CONCLUSIONS}

It can be concluded that yeast can be used in feeding lambs after treatment with yeast Saccharomy cerevisiaeBy 3 (gm / head / day), which led to an improvement in the weights of lambs and their weight increases with an improvement in the efficiency of feed conversion. The use of yeast is one of the ways to improve the vital feed at the lowest cost and ease of procedure.

\section{REFERENCES}

1. Abu Salwa, Karim Hammadi Muhanna (2016). impactSubstituting different proportions of crushed dates for barley with or without the addition of yeast the bread (Saccharomyces cerevisiae) In the performance of the Arabian lambsmemory. Master Thesis . Albasrah university . 
2. Ghalibbi, Hana Ali Jabbar; Al-Ghalbi, Maytham Khalaf Ali; Shuwaya, Ehsan Ali and Janam, Ahmed Ali (2017). The effect of using yeast Saccharomyces cerevisiae and bakzin in hematological and biochemical parameters of serum of Arabized lambs., Journal of the College of Education for Pure Sciences -Dhi Qar University, Issue 1(7) 174-183.

3. Ahmed, Mansour Mohamed; Mona, Muhannad Jamil; Noah, Abdullah; Kahil, Othman; Hanafi, Faisal; Tohme, Muhammad (2016). Effect of live Saccharomyces cerevisiae yeast on milk production and live weight in Awassi sheep. The Syrian Journal of Agricultural Research, Volume (3), Issue (1) 107-114.

4. Antunović Z, Šperanda M, Amidžić D, Šerić V, Stainer Z, Domačinović M, Boli F. (2006).Probiotic application in lambs nutrition. Krmiva. 48:175-180.

5. Moallem, U., Lehrer, H., Livshitz, L., Zachut, M., Yakoby, S., (2009).The effects of live yeast supplementation to dairy cows during the hot season on production, feed efficiency, and digestibility. J. Dairy Sci. 92, 343-351.

6. Schingoethe, DJ, Linke, KN, Kalscheur, KF, Hippen, AR, Rennich, DR, Yoon, I., (2004). Feed efficiency of mid-lactation dairy cows fed yeast culture during summer. J.Dairy Sci. 87, 4178-4181.

7. Shriver-Munsch, CM, Ramsing, EM, Males, JR, Sanchez, WK, Yoon, I., Bobe, G., (2011).Effect of various dosages of Saccharomyces cerevisiae fermentation product on reproductive function in multiparous dairy cows. In: Page 38 in Proc. 13th Annual Northwest Reproductive Sciences Symposium. Corvallis, OR.

8. Musa HH, Wu SL, Zhu CH, Seri HI, Zhu GQ. (2009).The potential benefits of probiotics in animal production and health. J Anim Vet Adv. 8:313-321.

9. El-Ghani AA. (2004).Influence of diet supplementation with yeast culture (Saccharomyces cerevisiae) on performance of Zaraibi goats. Small Rumin Res. 52:223-229.

10. Elaref, MY; Hamdon, HAM; Nayel, UA; Salem, AZM; Anele, UY (2020).Influence of dietary supplementation of yeast on milk composition and lactation curve behavior of Sohagi ewes, and the growth performance of their newborn lambs. Small Ruminant Research, (), 106176-doi:10.1016/j.smallrumres.2020.106176. 
ISSN Onlin:2708-9347, ISSN Print: 2708-9339 Volume 10, Issue 2 (2021) PP 74-79

https://jam.utq.edu.iq/index.php/main $\quad$ https://doi.org/10.54174/UTJagr.Vo10.N2/09 